\title{
ANALISIS ATAS PEMANFAATAN APLIKASI e-SPT OLEH WAJIB PAJAK TERDAFTAR DI KPP PRTAMA DENPASAR TIMUR
}

\author{
Dewi Bali Astuti \\ Jurusan Akuntansi Programa Diploma III, \\ Universitas Pendidikan Ganesha, Singaraja \\ e-mail dewi.baliaztuti@yahoo.com
}

\begin{abstract}
Abstrak
Dalam rangka meningkatkan kualitas pelayanan pajak terhadap wajib pajak, Direktorat Jenderal Pajak menerapkan sistem elektronik (e-SPT) dalam pelaporan pajak. Tujuan dari penelitian ini adalah untuk mengetahui Pemanfaatan Aplikasi e-SPT Oleh Wajib Pajak Terdaftar Di KPP Pratama Denpasar Timur ditinjau dari Analisis Pemanfaatan e-SPT. Lokasi penelitian ini dilakukan di Jalan kapten Tantular No. 4 Renon GKN II Denpasar. Jenis data yang dipergunakan adalah data kuantitatif. Sumber data yang dipergunakan adalah data sekunder, teknik pengumpulan data dilakukan dengan wawancara dan dokumentasi yang selanjutnya dianaliasis dengan teknik analisis deskriptif kuantitatif.

Hasil penelitian menunjukan bahwa kinerja KPP Pratama Denpasar Timur dalam memanfaatkan aplikasi e-SPT dinilai sangat baik dilihat dari segi penerapan program e-SPT ternyata program ini efektif dan efisien khusunya bagi wajib pajak hal ini disebabkan karena wajib pajak lebih suka melaporkan SPT masa PPN, PPH Pasal 21/26, dan PPH Pasal 25.
\end{abstract}

Kata kunci: E-SPT Masa PPN, Efisiensi Pengisian SPT

Abstract

In order to increase the quality of service towards taxpayer, Directorate General of Taxation (DGT) applies electronic system (e-SPT) in tax report. This research aimed at finding out the utilization of e-SPT application by taxpayer registered at KPP Pratama Denpasar Timur reviewed from utilization analysis of e-SPT. The location of this research took place at Jalan Kapten Tantulas No. 4 Renon GKN II Denpasar. The type of data used were kuantitatif data. The source of data used were secondary data, technique of data colletion done through interview and the documentation further analysed by using analysis technique of descriptive quantitative.

The result of research showed the performance of KPP Pratama Denpasar Timur in utilizing eSPT application was considered excellent in terms of programme application that showing it effective and efficient especially for taxpayer. This is due to the taxpayer prefered to report Periodic Tax Return Value Added Tax (SPT masa PPN), Income Tax (PPH) section 21/26.

Keywords: Electronic Periodic Tax Return Value Added Tax 


\section{Pendahuluan}

Pajak adalah kontribusi wajib kepada negara yang terutang oleh orang pribadi maupun badan yang bersifat memaksa berdasarkan Undang-Undang, dengan tidak mendapatkan imbalan secara langsung dan digunakan untuk keperluan negara bagi sebesar-besarnya kemakmuran rakyat. Hal tersebut merupakan pengertian pajak dan tujuan dari pengenaannya.

Pajak merupakan sumber pendapatan negara yang sangat penting peranannya dalam pembangunan, saat ini pajak menjadi sumber utama pendapatan negara dengan proporsi lebih dari $70 \%$ dari total Anggaran Pendapatan dan Belanja Negara sehingga diperlukan Sistem Administrasi Perpajakan yang memadai agar seluruh penerimaan negara dari sektor pajak dapat terealisasikan dengan baik.

Salah satu Sistem Administrasi Perpajakan di Indonesia adalah Self Assessment sebagai Sistem Pemungutan Pajak. Sistem Administrasi Perpajakan di Indonesia, mulai dikembangkan dengan beberapa aplikasi. Salah satunya adalah e-SPT yang dapat mempermudah proses pelaporan SPT secara elektronik.

Tujuan diterapkannya e-SPT diantaranya adalah:

a. Penerapan sistem administrasi modern perpajakan pada Kantor Pelayanan Pajak (KPP) dapat diukur dan dipantau, mengingat pada sistem tradisional sangat sulit dilakukan.

b. Penerapan sistem administrasi modern perpajakan yang meliputi penerapan e-SPT terhadap efisiensi pengisian SPT menurut wajib pajak dapat ditelaah dan dikaji untuk pencapaian tujuan bersama.

c. Sebagai informasi dan bahan evaluasi dan penerapan sistem administrasi modern perpajakan sehingga dapat mendorong digilirkannya reformasi administrasi perpajakan jangka menengah oleh DJP yang menjadi prioritas dalam reformasi perpajakan terutama dalam melanjutkan penerapan sistem administrasi modern perpajakan pada kantorkantor pajak lainnya di seluruh Indonesia.

d. Sebagai informasi yang perlu diperhatikan bagi DJP dalam memahami aspek-aspek yang berpengaruh terhadap kepatuhan wajib pajak sehingga merupakan salah satu tujuan dari modernisasi perpajakan melalui penerapan sistem administrasi modern perpajakan.

e. Sebagai informasi yang bermanfaat bagi masyarakat perpajakan di Indonesia.

f. Sebagai informasi yang bermanfaat bagi masyarakat baik secara umum maupun secara khusus sehingga dapat mendorong kepercayaan masyarakat terhadap administrasi perpajakan di Indonesia.

\section{Kelebihan e-SPT}

a) Penyampaian SPT dapat dilakukan secara cepat dan aman, karena lampiran dalam bentuk media $C D /$ flash disk

b) Data perpajakan terorganisasi dengan baik.

c) Sistem aplikasi e-SPT mengorganisasikan data perpajakan perusahaan dengan baik dan sistematis.

d) Penghitungan dilakukan secara cepat dan tepat karena menggunakan sistem komputer.

e) Kemudahan dalam penghitungan dan pembuatan Laporan Pajak.

f) Data yang disampaikan WP selalu lengkap, karena penomoran formulir dengan menggunakan sistem komputer.

g) Menghindari pemborosan penggunaan kertas serta berkurangnya pekerjaanpekerjaan klerikal perekaman SPT yang memakan sumber daya yang cukup banyak.

\section{Metode Penelitian}

Sesuai dengan tujuan penelitian ini, untuk mengetahui kinerja KPP Pratama Denpasar Timur dalam Penerapan Aplikasi e-SPT. Instansi Pemerintah ini tergolong penelitian yang bersifat studi khusus yaitu penelitian yang lebih banyak mengumpulkan data 
yang berupa angka dan diuraikan secara menyeluruh, teliti, dan sesuai dengan persoalan yang akan dipecahkan.

Dalam penelitian ini digunakan metode penelitian deskriptif kuantitatif yakni berupa angka yang dapat dihitung dengan satuan. Dalam kegiatan pengumpulan data penulis menggunakan 2 metode yaitu Wawancara dan dokumentasi. Setelah data yang diperlukan diperoleh selanjutnya data tersebut akan di analisis dengan menggunakan teknik analisis deskriptif kuantitatif. Kinerja Perpajakan perusahaan diinformasikan dari system sumber daya perusahaan berupa laporan tentang perpajakan yang terdiri dari : Laporan Surat Pemberitahuan SPT Masa dan Surat Pemberitahuan SPT Tahunan dan laporan lain yang dianggap perlu untuk mendukung pengambilan keputusan. Dari Analisis tersebut akan diketahui kinerja Instansi dalam Khususnya Memanfaatkan e-SPT Masa PPN, PPH Pasal 21/26 dan PPH Pasal 25 apakah dengan adanya program baru ini Instansi tersebut lebih diuntungkan atau tidak.

jenis data yang digunakan dalam penelitian ini adalah data kuantitatif yaitu Data kuantitatif adalah data yang berupa angka-angka untuk menganalisis data sebelum dan sesudah dilakuknnya aplikasi e-SPT pada KPP Pratama denpasar Timur Sumber Data yang digunakan adalah data sekunder Meliputi. Data yang digunakan adalah data 12 bulan sebelum dan sesudah 12 bulan di tahun 2014 dilakukannya Aplikasi e-SPT Masa PPN, PPH Pasal 21/26 dan PPH Pasal 25 pada KPP Pratama Denpasar Timur. Data yang diperoleh berasal dari data yang dimiliki KPP Pratama Denpasar Timur.

\section{Hasil dan Pembahasan}

\section{A. Analisis Atas Pemanfaatan Aplikasi e-SPT Oleh wajib Pajak Terdaftar di KPP Pratama Denpasar Timur}

Dalam Melaporkan SPT Masa PPN, secara Manual Pengusaha Kena Pajak (PKP) mancatat, menghitung, menyetor dan melaporkan seluruh hal yang terkait dengan kewajiban pajaknya kepada KPP sesuai dengan domisilinya secara langsung. Sedangkan untuk mekanisme pembayaran dan pelaporan SPT Masa tersebut secara manual, antara Pengusaha Kena Pajak dengan Aparat Pajak ( Fiskus ) berinteraksi secara langsung. Dan dalam pelaporan SPT Masa PPN harus disertai seluruh lampiran yang mendukung dalam pengisian SPT tersebut.

Dan dalam melaporkan SPT Masa PPN lampiran pendukungnya berjumlah sangat banyak pelaporan SPT ini sedikit merepotkan. sajikan Pelaporan SPT Masa PPN secara Elektronik (e-SPT) yang merupakan fasilitas Direktorat Jendral Pajak ( DJP) diharapkan dapat memberikan kemudahan kepada Pengusaha Kena Pajak ( PKP ) dalam melaporkan SPT Masa PPN.

Dalam melaporkan SPT PPH pasal 21/26 setiap karyawan dikenakan pajak Penghasilan atas gaji yang diperoleh dari perusahaan yang memberi kerja, dan pada dasarnya Pajak tersebut menjadi tanggung jawab perusahaan untuk membayarkannya langsung ke DJP, dan sama hal dengan PPN agar lebih mudah dan efisien dalam melaporkan SPT PPh pasal 21/26 digunakannya aplikasi e-SPT.

Dan selain itu juga dalam melaporkan PPH pasal 25 ini adalah Pembayaran pajak penghasilan secara angsuran yang tujuannya untuk meringankan beban wajip pajak maka dari itu Penyampaian menggunakan e-SPT adalah solusi yang dapat dilakukan secara cepat dan aman, karena lampiran dalam bentuk media CD atau Disket dan perhitungannya pun dilakukan dengan tepat dan cepat karena menggunakan sistem komputer serta memberi kemudahan untuk melaporkann data perpajakan. 


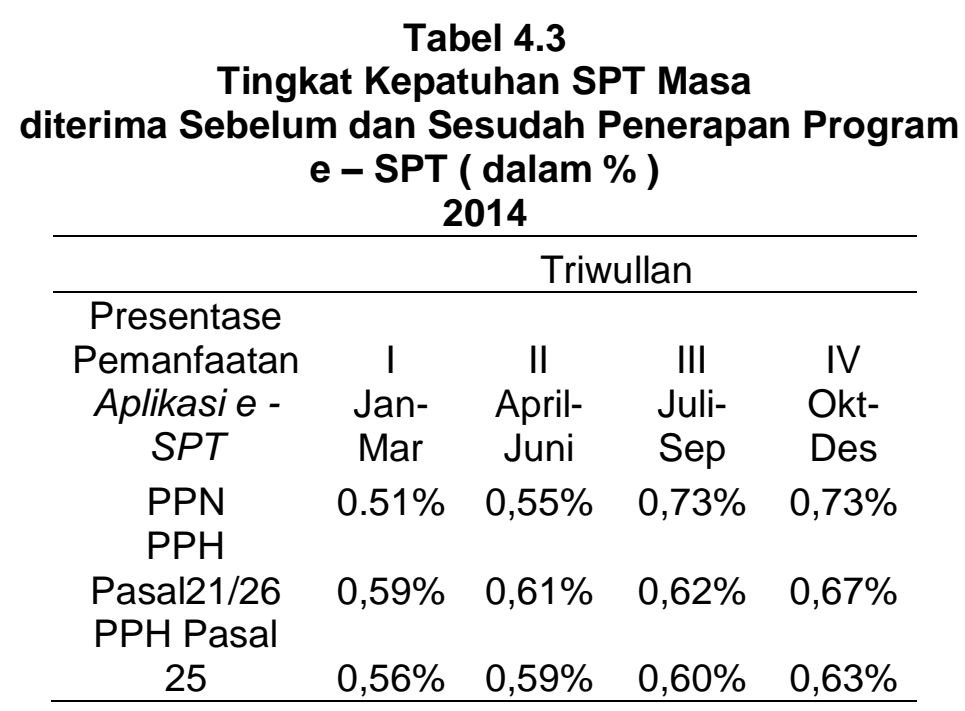

Dari Tabel diatas dapat diketahui persentase perkembangan pemanfaatan aplikasi $e$ SPT terhadap penyampaian SPT secara manual. Perbandingan data tersebut dilihat dari penyampaian tiap jenis SPT yang disampaikan oleh Wajib Pajak, dalam hal ini, Pemanfaatan e-SPT diukur melalui Penyampaian SPT Masa PPN, PPH Pasal 21/26, dan PPH Pasal 25, Diketahui bahwa dari Presentase penyampaian e -SPT PPN Triwullan I Hingga IV tahun 2014 mengalami peningkatan, begitu juga dengan PPH Pasal 21/26 dan PPH Pasal 25 ikut juga meningkat dari triwullan I hingga IV. Jadi dalam tabel Presentase diatas pemanfaatan e - SPT sangat diminati oleh Wajib pajak dibandingkan dengan SPT Pelaporan Manual.

Dan ini berarti program penerapan e-SPT tersebut efektif khususnya bagi wajib pajak dan bagi Kantor Pelayanan Pajak (KPP). Hal ini disebabkan karena, wajib pajak lebih suka melaporkan SPT Masa PPN, PPH pasal 21/26, dan PPH Pasal 25 nya dengan menggunakan program e-SPT dari pada manual. Fenomena semacam ini terjadi karena beberapa faktor yang melatar belakanginya diantaranya penyampaian SPT melalui sistem aplikasi e-SPT dilakukan secara cepat, mudah dan aman. Karena lampirannya dalam bentuk media CD/Disket, maka data perpajakan dapat terorganisasi dengan baik.

Disamping itu, sistem aplikasi e-SPT memiliki kelebihan yang tidak dimiliki pelaporan secara manual yaitu : selain dapat mengorganisasikan data perpajakan perusahaan dengan baik dan sistematis perhitungannya pun dilakukan secara cepat dan tepat karena menggunakan sitem komputer.Kelebihan lain dari aplikasi e-SPT, ini dapat memberikan kemudahan bagi wajib pajak dalam membuat laporan pajak dan WP dapat secara langsung melakukan pembetulan atau koreksi pada SPT induk maupun lampiran SPT bila terdapat kesalahan pemasukan data karena sistem aplikasi e-SPT memiliki fasilitas checking.

\section{Simpul dan Saran}

Berdasarkan hasil evaluasi yang telah dilakukan pada Bab IV dan ditunjang dari data data pada bab sebelumnya maka dapat disimpulkan bahwa Dari hasil pengujian data dapat ditarik kesimpulan bahwa :

Diketahui dari Presentase Perkembangan sebelum atau sesudah Pemanfaatan e -SPT, dalam hal ini pemanfaatan e -SPT PPN mengalami peningkatan di tahun 2014 triwullan I sebesar 0,51\%, II Sebesar 0,55\%, III sebesar 0,73\%, dan IV sebesar 0,73\%. Itu berarti Wajib pajak lebih suka menggunakann Aplikasi e- SPT masa PPN ketimbang pelaporan secara manual. Dikuti juga Presentase Perkembangan Sebelum atau Sesudah pemanfaatan e-SPT PPH pasal 21/26 mengalami peningkatan sama dengan SPT masa PPN dengan Tahun pajak 2014 Triwullan I sebesar 0,59\%, II sebesar 0,61\%, III sebesar 0,62\%, dan IV 0,67\%. Dan yang terakhir Presentase Perkembangan Sebelum atau Sesudah pemanfaatan e-SPT 
PPH Pasal 25 turut serta mengalami peningkatan sama halnya dengan PPN dan PPH pasal 21/.26 dengan tahun pajak 2014 Triwullan I sebesar 0,56\%, II sebesa5 0,59\%. III sebesar $0,60 \%$, IV sebesar $0,63 \%$.

Dari kesimpulan diatas dapat dituliskan beberapa implikasi yang dapat diharapkan dalam penelitian ini adalah :

Penerapan program e-SPT yang dilakukan KPP Pratama Denpasar Timur sebagai usaha meningkatkan kepatuhan wajib pajak ternyata mampu meningkatkan Pengusaha Kena Pajak ( PKP )hal ini dikarenakan KPP Pratama Denpasar Timur selalu meningkatkan mutu layanannnya kepada masyarakat. Jaringan komunikasi perpajakan untuk menjaring data pemilik NPWP (Nomor Pokok Wajib Pajak), dan penyelesaian laporan perpajakan dan lain-lain semakin baik dan bisa dipercaya Dengan adanya peningkatan kepatuhan Wajib Pajak setelah adanya program e-SPT dalam melaporkan SPT Masa PPN, PPh Pasal 21/26 dan PPH Pasal 25, maka diharapkan kinerja Direktorat Jendral Pajak beserta Kantor Wilayahnya untuk dapat meningkatkan kinerjannya lebih baik lagi kedapannya, salah satunya dengan memberikan penyuluhan - penyuluhan mengenai pentingnya membayar pajak tepat waktu, serta memberikan pelayanan yang terbaik khususnya wajib pajak. Dari penelitian ini diharapkan dapat memacu peningkatan penerimaan pajak mengingat pajak merupakan sumber pendapatan pemerintah. Pemerintah harus mendukung program program yang berhubungan dengan peningkatan penerimaan pajak dan bekerjasama dengan Kantor Pelayanan Pajak (KPP) khususnya Direktorat Jendral Pajak (DJP)

\section{Daftar Pustaka`}

Peraturan Direktur Jenderal Pajak Nomor PER - 6/PJ/2009 tentang Tata Cara PenyampaianSurat Pemberitahuan Dalam Bentuk Elektronik.

PMK No. 152/PMK.03/2009 Tentang Bentuk dan Isi Surat Pemberitahuan, serta Tata Cara Pengambilan Pengisian, Penandatanganan, dan Penyampaian Surat Pemberitahuan

PER-39/PJ/2009 Tentang Surat Pemberitahuan Tahunan Pajak Penghasilan WajibPajak Badan Beserta Petunjuk Pengisiannya

Surat Edaran Nomor 94/PJ/2011 tentang Kewajiban Penyampaian SPT Masa PPN dalam bentuk Data Elektronik (e-SPT) 